\title{
Physics Course Attitudes Scale for High School Students: A Validity and Reliability Study
}

\author{
Hulya Cermik ${ }^{(1}$, Izzet Kara ${ }^{(1, *}$
}

${ }^{1}$ Pamukkale University, Faculty of Education, Kınıklı Campus, 20070, Denizli, Turkey

\section{ARTICLE HISTORY}

Received: 08 May 2019

Revised: 24 December 2019

Accepted: 06 January 2020

\section{KEYWORDS}

Physics course,

Physics course attitudes scale,

Validity,

Reliability

\begin{abstract}
The purpose of this study is to develop an up-to-date scale with high validity and reliability that could reveal the attitudes of high school students towards the physics course. In the process of developing the scale in question, three independent samples were formed, and the data obtained from a total of 1118 high school students were analyzed. Firstly, the opinions of 152 high school students on the physics course were collected in written form, and a 58-item pool was formed. Afterwards, the draft scale which was designed as a 5-point Likerttype scale whose items were reduced to 43 based on expert opinions was applied on 602 high school students. Based on the data obtained, an exploratory factor analysis (EFA) was carried out. With the EFA, it is determined that 22 items of the scale have factor loads between 0.490 and 0.816 , while they explain $66.276 \%$ of the total variance and are distributed under four factors. These factors are named as interest, unwillingness, academic self and necessity. Additionally, these four factors are significantly correlated, and there is no autocorrelation problem. For all items in the scale, item-factor and item-test correlation coefficients were calculated, and it is determined that each item is consistent with not only the factor it is under but also the entire test.
\end{abstract}

\section{INTRODUCTION}

Today, individuals who go through the education and training process are well-equipped in the field of physics, which has, undoubtedly, an important effect on their personal lives, on their professional development, and, moreover, on scientific developments in national and international arenas. This fact is also considered by educational institutions in determining the learning outcomes of the "physics course". Since knowledge of physics is of high importance during their education, students take physics courses usually in the first year of their high school education. However, physics course is considered to be difficult in both learning and teaching it (Angell, Guttersrud, Henriksen \& Isnes, 2004; Mualem \& Eylon, 2007; Mulhall \& Gunstone, 2008). In addition, students find physics course difficult and also, they think it is boring (Williams, Stanisstreet, Spall \& Boyes, 2003). It is also stated that the academic success level of students in physics education is rather lower than that in other disciplines (Rivard \& Straw, 2000). That students see physics and physics classes difficult and boring or have lower success in comparison to other disciplines is a significant problem as well. Therefore, it is definitely

CONTACT: İzzet Kara $\bigotimes$ ikara@pau.edu.tr of Mathematic and Sciences Education, Kınıklı Campus, 20070, Denizli, Turkey 
necessary to determine and eliminate the source of this problem. Determining students' attitudes towards the physics course can be one of the best ways to solve such a problem.

İnceoğlu (2010) defined attitude as a preliminary tendency of a mental, emotional and behavioral reaction organized by the person towards any object, social issue or event based on their experience, knowledge, emotions and urges. Developing a positive attitude towards a subject, in addition to willingness to participate in the class, involves a set of behaviors in the form of satisfaction from responding, acceptance of the value of the course and being an advocate of this acceptance (Özçelik, 1998). Papanastasiou and Zembylas (2002) stated that a positive attitude towards science increases the success of students in this field, whereas success does not guarantee positive attitudes. Another study emphasized that physics teachers should focus more on the attitudes of their students towards learning physics rather than focusing merely on their learning of physics (Veloo, Nor, \& Khalid, 2015). This situation reveals the necessity of measurement instruments that may demonstrate the attitudes of students towards the physics course.

In the related literature, it is seen that scales have been developed to determine attitudes towards physics for different objectives (Douglas, Yale, Bennett, Haugan, \& Bryan, 2014; Faour \& Ayoubi, 2018; Moll \& Milner-Bolotin, 2009; Olusola \& Rotimi, 2012). The common characteristic of these studies is determination of the effects of attitude on the physics course. For example, the scale that was developed by Kurnaz and Yiğit (2010) aimed to determine the attitudes of high school students towards physics, physics-related topics and studies that are conducted. The 4-point Likert-type scale that was applied on 841 students who were enrolled at seven different types of high schools was given its final form by conducting an EFA. In the scale with the Cronbach's Alpha internal consistency coefficient of 0.95 and three factors, the factors were named as 'valuing physics', 'turning physics into a behavior' and 'point of view towards physics. In another study Tekbiyık and Akdeniz (2010) developed an up-to-date physics attitudes scale for high school students. The sample of the study consisted of 166 ninthgrade students. The 30-item, 5-point Likert-type scale that was given its final form by EFA had 4 factors named as importance, comprehension, necessity and interest. In their study Nalçac1, Akarsu and Kariper (2011) developed a 30-items scale for measuring the attitudes of high school students towards the field of physics by reviewing a number of physics attitude scales. The scale was developed as a 5-point Likert-type scale consisting of 30 items including 12 negative and 18 positive statements. The analyses that were conducted on the data collected from 303 students in total were highly limited. As a result of these analyses, it was stated that no item was removed from the scale as there was no item with a correlation value under 0.20 , and the Cronbach's Alpha reliability coefficient of the scale was reported as 0.94 . In another study, Kaur and Zhao (2017) developed a physics attitude scale by using data obtained from 624 students at the ages of 15-18 in India. Their scale consisted of five dimensions as Enthusiasm toward Physics, Physics Learning, Physics as a Process, Physics Teacher and Physics as a Future Vocation. In addition, it is possible to encounter a set of studies in the literature on the development or adaptation of physics attitudes scales (Özyürek \& Eryılmaz, 2001; Taşlıdere, 2002; Taşlıdere \& Eryılmaz, 2009; Tekbıyık, 2010; Uz \& Eryılmaz, 1999). As seen, the scales in question usually focused on revealing the attitudes of students towards physics or physics-related topics. There is, on the other hand, a limitation in the scales that were developed to reveal attitudes of high school students towards the physics course. In the literature, under this title only the 36-item, 5-point Likert-type "Physics Course Attitudes Scale" that was developed by Akpinar (2006) can be encountered. This scale consists of six factors; namely, interest in the physics course, the concept of self in relation to the physics course, willingness to work on physics outside the school, thoughts on the relationship between the physics course and life, thoughts on the work required by the physics course and general 
thoughts on the physics course. It is not possible to say that this scale, which was prepared as a physics course attitudes scale, is up to date.

This study, which was carried out based on the importance of revealing the attitudes of high school students towards the physics course, was conducted to develop an up to date, valid and reliable measurement instrument that could reveal students' attitudes towards the topic.

\section{METHOD}

\subsection{Samples}

In this study, three independent samples were formed out of 1118 high school students studying at the city center of the province of Denizli in Turkey and as stated by Seçer (2015) different samples were created for conducting scale development studies.

The first sample consisted of 152 high school students whose opinions were consulted to create the item pool of the scale. The students in this group answered the open-ended question directed towards themselves during the process of creating attitude items. Among the students, 82 $(53.9 \%)$ were female, and $70(46.1 \%)$ were male. The second sample completed the 43 -item draft scale that was prepared to reveal the attitudes of high school students towards the physics course. There was a total of 602 high school students in this sample. Among these students, 330 $(54.8 \%)$ were female, and $272(45.2 \%)$ were male. $167(27.5 \%)$ of the students were enrolled at Science High Schools, 368 (61.1\%) were students of Anatolian High Schools, and 67 (11.1\%) were students of Religious Vocational High Schools. An exploratory factor analysis (EFA) was conducted on the data obtained from the second sample. For a sufficient sample size for factor analysis, Comrey and Lee (1992) stated that 300 is good, and 500 is very good, and while Kline (1994) stated that 200 individuals are sufficient for a sample size with reliable factors and they also recommended the sample size to be 10 times more than the number of items. Considering these issues, it was concluded that 602 high school students in the second sample were sufficient.

The third sample consisted of 364 high school students and was formed to confirm the construct to be analyzed. A confirmatory factor analysis (CFA) was carried out on the data obtained from this group. In addition to a sample size of larger than 300, as the scale that was applied on the group consisted of 22 items, it was ensured that the number of observations per item was higher than 10 individuals. Additionally, a particular attention was given to form a similar group of participants in the third sample by keeping in mind the percentage values of the genders and types of high schools in the second sample. Among the students in this group, $202(55.5 \%)$ were female, and $162(44.5 \%)$ were male. Of these students, 103 (28.3\%) were Science High School students, 219 (60.2\%) were Anatolian High School students, and 42 (11.5\%) were Religious Vocational High School students.

\subsection{Developing the measurement instrument}

Within the scope of the development of the Physics Course Attitudes Scale, firstly, the opinions of the high school students in the first sample about the physics course were collected in writing. The data that were collected in written form from the 152 students in this group were examined, and an item pool of 58 items related to attitudes towards the physics course was created. The items in question were submitted for the opinions of a total of seven experts including two measurement and assessment, two curriculum development, two physics and one linguistics experts. Based on all the feedback received from the experts, the items that did not express attitudes towards the physics course and those that expressed similar meanings were removed. By eliminating the problems in the linguistic and semantic aspects of the items, a draft scale form consisting of 43 items including 21 positive and 22 negative statements was created. The scale items were designed to be scored as 5-point Likert-type items; namely, (1) Absolutely 
agree, (2) Agree, (3) Somehow agree, (4) Disagree and (5) Absolutely disagree. The lowest possible score from this scale was 43, while the highest was 215 .

\subsection{Data analysis}

To conduct the validity and reliability analyses of the measurement instrument, the data obtained from the second and third samples were uploaded onto the SPSS 22.00 and AMOS 16 software and analyzed. Firstly, for the purpose of determining the construct validity of the scale, $\mathrm{KMO}$ and Bartlett's tests were carried out on the data obtained from the second sample to see the data's suitability for factor analysis. Based on the obtained values, an EFA was carried out on the data. Additionally, for each item in the scale, the item-factor and item-test correlation values were calculated with a purpose to see whether each item was consistent with its factor and the entire scale. Afterwards, a CFA was conducted on the data obtained from the third sample. To determine the reliability of the scale, the Cronbach's Alpha realibility coefficiency method was used.

\section{FINDINGS}

\subsection{Findings on validity}

Construct validity was applied to the scale in order to determine the extent to which the attitude scale as the measurement instrument can measure the variable it aims to measure without confusing it with other variables (Balc1, 2009). To determine the construct validity of the Physics Course Attitudes Scale, firstly, Kaiser-Meyer-Olkin (KMO) and Bartlett's test analyses were conducted on the data collected from the second sample, and the values were obtained as $\mathrm{KMO}=0.945$; Bartlett's test value $\chi^{2}=7782.179 ; \mathrm{df}=231$ ( $\left.\mathrm{p}=0.000\right)$. As $\mathrm{KMO}$ values of higher than 0.60 are seen to be sufficient for factor analysis in the social sciences (Büyüköztürk, 2002), it was decided that factor analysis could be conducted on the 43-item scale.

In Exploratory Factor Analysis, Principal Component Analysis (PCA) is a technique that is used to reveal whether or not the items in a scale could be divided into a lower number of factors that exclude each other (Büyüköztürk, 2002). Moreover, to clarify the factors that are formed by gathering the items, the Varimax orthogonal rotation technique was applied. Accordingly, PCA was carried out on the data, the Varimax orthogonal rotation technique was applied to see whether or not the scale could be divided into independent factors, and the factor loads were examined. Items that have factor load values under 0.30 and those that are distributed under more than one factor with less than a difference of 0.10 between their factors loads need to be removed from the scale (Balc1, 2009; Büyüköztürk, 2002). As a result of the analyses in this study, the eigenvalues of the items had to be at least 1.00, while their factor loads at least 0.45 . Items that were distributed under multiple factors were eliminated, 21 items were removed, and the analyses were carried out on the remaining 22 items.

A total of 22 items remaining in the scale were found to be distributed under four factors. Among these items, 12 had positive and 10 had negative statements. Without subjecting the remaining 22 items to rotation, it was found that the factor loads varied between 0.477 and 0.823. After subjecting the items to the Varimax orthogonal rotation technique, these factor loads were found to vary between 0.490 and 0.816 . Moreover, it was determined that the items and factors in the scale explained $66.276 \%$ of the total variance. As it was stated that this ratio needs to be at least 52\% (Henson \& Roberts, 2006), the obtained value was found sufficient. This finding obtained by EFA is shown in Figure 1 based on the eigenvalues. In Figure 1, it is seen that there were steep drops in the first four factors, and therefore, these factors had significant contribution to the variance. 


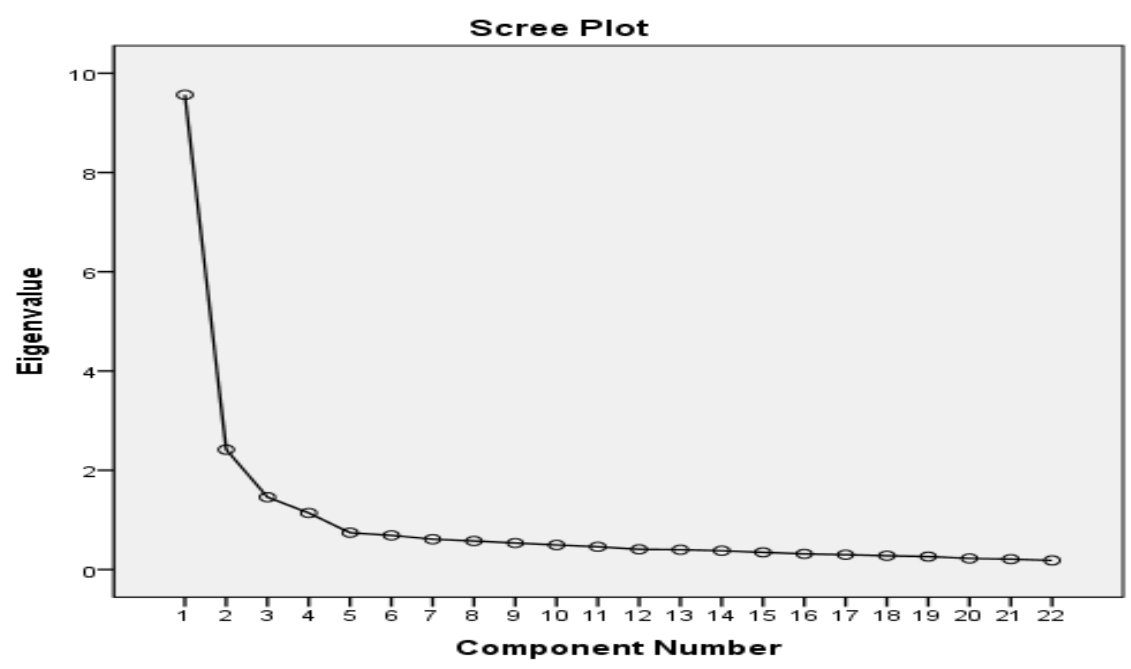

Figure 1. Eigenvalues based on the factors

Furthermore, the factors were named by examining the contents of the items gathered under these four factors. There were six items in each of the factors named interest and unwillingness, while there were five items in each of the factors named academic self and necessity. Table 1 presents findings on the item loads of the remaining 22 items based on the factors, factor eigenvalues and variance explanation ratios.

Table 1. Physics Course Attitudes Scale common variances, item factor loads, variances explained by sub-scales and item analysis results

\begin{tabular}{|c|c|c|c|c|c|}
\hline Items & $\begin{array}{l}\text { Common } \\
\text { variance }\end{array}$ & $\begin{array}{c}\mathrm{F} 1 \\
\text { Interest }\end{array}$ & $\begin{array}{c}\mathrm{F} 2 \\
\text { Unwillingness }\end{array}$ & $\begin{array}{c}\mathrm{F} 3 \\
\text { Academic self }\end{array}$ & $\begin{array}{c}\text { F4 } \\
\text { Necessity }\end{array}$ \\
\hline $\mathrm{I} 37$ & 0.766 & 0.805 & & & \\
\hline I43 & 0.632 & 0.780 & & & \\
\hline I38 & 0.702 & 0.750 & & & \\
\hline $\mathrm{I} 32$ & 0.685 & 0.710 & & & \\
\hline $\mathrm{I} 33$ & 0.762 & 0.677 & & & \\
\hline $\mathrm{I} 30$ & 0.673 & 0.655 & & & \\
\hline $\mathrm{I} 20$ & 0.733 & & 0.816 & & \\
\hline I19 & 0.715 & & 0.807 & & \\
\hline $\mathrm{I} 22$ & 0.754 & & 0.785 & & \\
\hline $\mathrm{I} 23$ & 0.775 & & 0.767 & & \\
\hline $\mathrm{I} 27$ & 0.725 & & 0.760 & & \\
\hline $\mathrm{I} 26$ & 0.519 & & 0.633 & & \\
\hline $\mathrm{I} 2$ & 0.686 & & & 0.773 & \\
\hline I1 & 0.720 & & & 0.750 & \\
\hline I5 & 0.635 & & & 0.688 & \\
\hline $\mathrm{I} 3$ & 0.662 & & & 0.576 & \\
\hline I7 & 0.662 & & & 0.566 & \\
\hline I9 & 0.652 & & & & 0.765 \\
\hline $\mathrm{I} 10$ & 0.670 & & & & 0.748 \\
\hline I11 & 0.628 & & & & 0.711 \\
\hline I14 & 0.510 & & & & 0.578 \\
\hline $\mathrm{I} 12$ & 0.507 & & & & 0.490 \\
\hline Eigenvalue & & 9.566 & 2,417 & 1,458 & 1.140 \\
\hline Explained variance & & 43.480 & 10.987 & 6.629 & 5.180 \\
\hline Total variance & & & & $6 \%$ & \\
\hline
\end{tabular}


As seen in Table 1, the factor loads of the items in the factor interest of the scale varied between 0.655 and 0.805 . The eigenvalue of this factor in the general scale was 9.566, and its contribution to the general variance was $43.480 \%$. The factor loads of the items in the factor unwillingness varied between 0.633 and 0.816 . The eigenvalue of this factor was 2.417 , and its contribution to the general variance was $10.987 \%$. The factor loads of the items in the factor academic self-varied between 0.566 and 0.773 . The eigenvalue of this factor was 1.458 , and its contribution to the general variance was $6.629 \%$. The factor loads of the items in the factor necessity varied between 0.490 and 0.765 . The eigenvalue of this factor was 1.140 , and its contribution to the general variance was $5.180 \%$.

In addition, the relationship between the four factors in the Physics Course Attitudes Scale was determined and for this reason, the correlations among the factors were checked. The findings are shown in Table 2.

Table 2. Correlation analysis results among the factors of the Physics Course Attitudes Scale

\begin{tabular}{lcccc}
\hline Factors & Interest & Unwillingness & Academic self & Necessity \\
\hline Interest & 1 & & & \\
\hline Unwillingness & $0.520^{* *}$ & 1 & & \\
\hline Academic Self & $0.627^{* *}$ & $0.600^{* *}$ & 1 & 1 \\
\hline Necessity & $0.645^{* *}$ & $0.487^{* *}$ & $0.488^{* *}$ & \\
\hline${ }^{* *} p<0.01$ & & &
\end{tabular}

As seen in Table 2, based on the correlation values among the factors of the Physics Course Attitudes Scale, the four factors were found to be significantly related, while there was no problem of autocorrelation.

The correlation coefficients between the scores obtained from all items and the scores obtained from the factors and the scale were also calculated, and the discrimination rate of each item was determined in order to reveal the degree to which each item served the general purpose of the factor it was in and the entire scale (Balc1, 2009; Korkmaz, Şahin, \& Yeşil, 2011). Table 3 presents the items of the scale: the first column shows the initial numbers of the items, the second column shows the updated numbers and negatively worded statements; and the other remaining columns present the items, item-factors, item subscale correlations and item-test correlations.

As seen in Table 3, the item-factor correlations were in the ranges of $0.620-0.817$ for the first factor, $0.603-0.812$ for the second factor, $0.599-0.707$ for the third factor and 0.442-0.652 for the fourth factor. Each item had a significant and positive relationship with the general scale $(p<0.001)$. When the item-test correlation coefficients for the entire scale were examined, the lowest correlation value was found as 0.438 , while the highest one was 0.789 . These coefficients that were obtained were the validity coefficients of all items, and they showed the consistency of the items with both their factor and the entire scale. In other words, these referred to the degree to which the scale served its general objective (Baykul, 2000).

The dimensions of the 'Physics Course Attitudes Scale' were determined to consist of four factors as a result of the EFA. To confirm these factors, the scale that consisted of 22 items was applied on the third sample that was selected independently of the second sample, and a CFA was carried out on the data. CFA is based on the relationship among observable and unobservable variables and testing them as hypotheses (Pohlmann, 2004). 
Table 3. Item-Test correlation analysis results

\begin{tabular}{|c|c|c|c|c|c|}
\hline 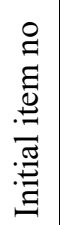 & 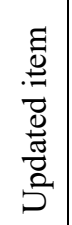 & Items & 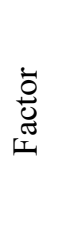 & 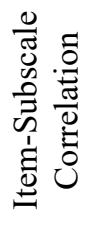 & 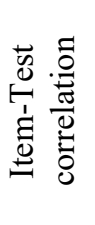 \\
\hline 37 & 22 & I look forward to the physics course. & $\mathrm{F} 1$ & 0.797 & 0.699 \\
\hline 43 & 13 & I enjoy daily repetition of what I learn in the physics course. & $\mathrm{F} 1$ & 0.620 & 0.505 \\
\hline 38 & 4 & I am more willing to study for the physics course than other courses. & $\mathrm{F} 1$ & 0.749 & 0.686 \\
\hline 32 & 8 & $\begin{array}{l}\text { I enjoy conducting in-depth research on what I learn in the physics } \\
\text { course. }\end{array}$ & F1 & 0.774 & 0.667 \\
\hline 33 & 21 & Topics of the physics course attract my interest. & $\mathrm{F} 1$ & 0.817 & 0.789 \\
\hline 30 & 17 & What I learn in the physics course excites me. & $\mathrm{F} 1$ & 0.756 & 0.692 \\
\hline 20 & $6^{*}$ & I see the physics course as waste of time. & $\mathrm{F} 2$ & 0.742 & 0.581 \\
\hline 19 & $15^{*}$ & I do not want to go to school on days of the physics course. & $\mathrm{F} 2$ & 0.760 & 0.601 \\
\hline 22 & $9^{*}$ & I am very bored during the physics course. & $\mathrm{F} 2$ & 0.802 & 0.691 \\
\hline 23 & $3^{*}$ & It is a torture for me to study for the physics course. & $\mathrm{F} 2$ & 0.812 & 0.722 \\
\hline 27 & $12^{*}$ & I would not attend the physics course if I were able to. & $\mathrm{F} 2$ & 0.762 & 0.690 \\
\hline 26 & $19^{*}$ & I feel very nervous during the physics course. & $\mathrm{F} 2$ & 0.603 & 0.514 \\
\hline 2 & $11^{*}$ & $\begin{array}{l}\text { Physics is not a subject I can learn by my own effort without } \\
\text { receiving special support. }\end{array}$ & F3 & 0.661 & 0.547 \\
\hline 1 & $1^{*}$ & $\begin{array}{l}\text { I do not believe I could be successful however much I study for the } \\
\text { physics course. }\end{array}$ & $\mathrm{F} 3$ & 0.707 & 0.617 \\
\hline 5 & $7^{*}$ & $\begin{array}{l}\text { I believe it is a miracle for me to understand the topics of the physics } \\
\text { course. }\end{array}$ & F3 & 0.599 & 0.545 \\
\hline 3 & 16 & I see myself as a successful student in the physics course. & F3 & 0.685 & 0.700 \\
\hline 7 & 14 & The physics course is among the courses I can learn easily. & F3 & 0.610 & 0.614 \\
\hline 9 & 2 & $\begin{array}{l}\text { I believe physics is an important subject that needs to be learnt by } \\
\text { everyone. }\end{array}$ & $\mathrm{F} 4$ & 0.624 & 0.517 \\
\hline 10 & 5 & $\begin{array}{l}\text { I believe our education would be lacking if there were no physics } \\
\text { courses in high school curricula. }\end{array}$ & F4 & 0.652 & 0.585 \\
\hline 11 & 18 & $\begin{array}{l}\text { I believe what I learn in the physics course makes my daily life } \\
\text { easier. }\end{array}$ & $\mathrm{F} 4$ & 0.625 & 0.558 \\
\hline 14 & 10 & The physics course is necessary for me to have a good occupation. & F4 & 0.468 & 0.438 \\
\hline 12 & $20^{*}$ & $\begin{array}{l}\text { I do not think the physics course will be useful for me after I graduate } \\
\text { from high school. }\end{array}$ & F4 & 0.442 & 0.501 \\
\hline
\end{tabular}

"Items with negative statements

According to the results that were obtained, the $\chi^{2} / \mathrm{df}$ ratio was calculated as 2.380 . A $\chi^{2} / \mathrm{df}$ ratio of 5 or lower is considered to be sufficient for model data fit (Schumacker \& Lomox, 2004; Wang, Lin \& Luarn, 2006). Moreover, a, $\chi^{2} / \mathrm{df}$ ratio of smaller than 3 shows a high model-data fit (Schumacker \& Lomox, 2004). The $\chi^{2} / \mathrm{df}$ value obtained as 2.380 in this study was a significant indicator that the measurement instrument had four dimensions. Another important index, the RMR value was calculated as 0.084 . It is known that the RMR index needs to be between 0 and 1 (Golob, 2003). Other fit indices were also calculated to assess the fit of the model. The calculated goodness of fit indices values were as: $\mathrm{IFI}=0.922 ; \mathrm{CFI}=0.921$; 
$\mathrm{GFI}=0.897 ; \mathrm{NFI}=0.872 ; \mathrm{AGFI}=0.866$, and $\mathrm{RFI}=0.849$. While it is generally acceptable for the aforementioned indices to be in the range of 0.80-0.90, values higher than 0.90 refer to a good fit (Yap \& Khong, 2006; Wang et al., 2006). The RMSEA analysis result was determined as 0.062. RMSEA values of lower than 0.10 show an acceptable level of model-data fit, while those lower than 0.05 are an indicator of a good fit (Bayram, 2013). Based on the $\chi^{2} / \mathrm{df}$, RMSEA and RMR values obtained from the data in the study, it may be stated that the measurement instrument consisted of four factors. Figure 2 below shows the standardized Structural Equation Modelling parameter values on the obtained findings.

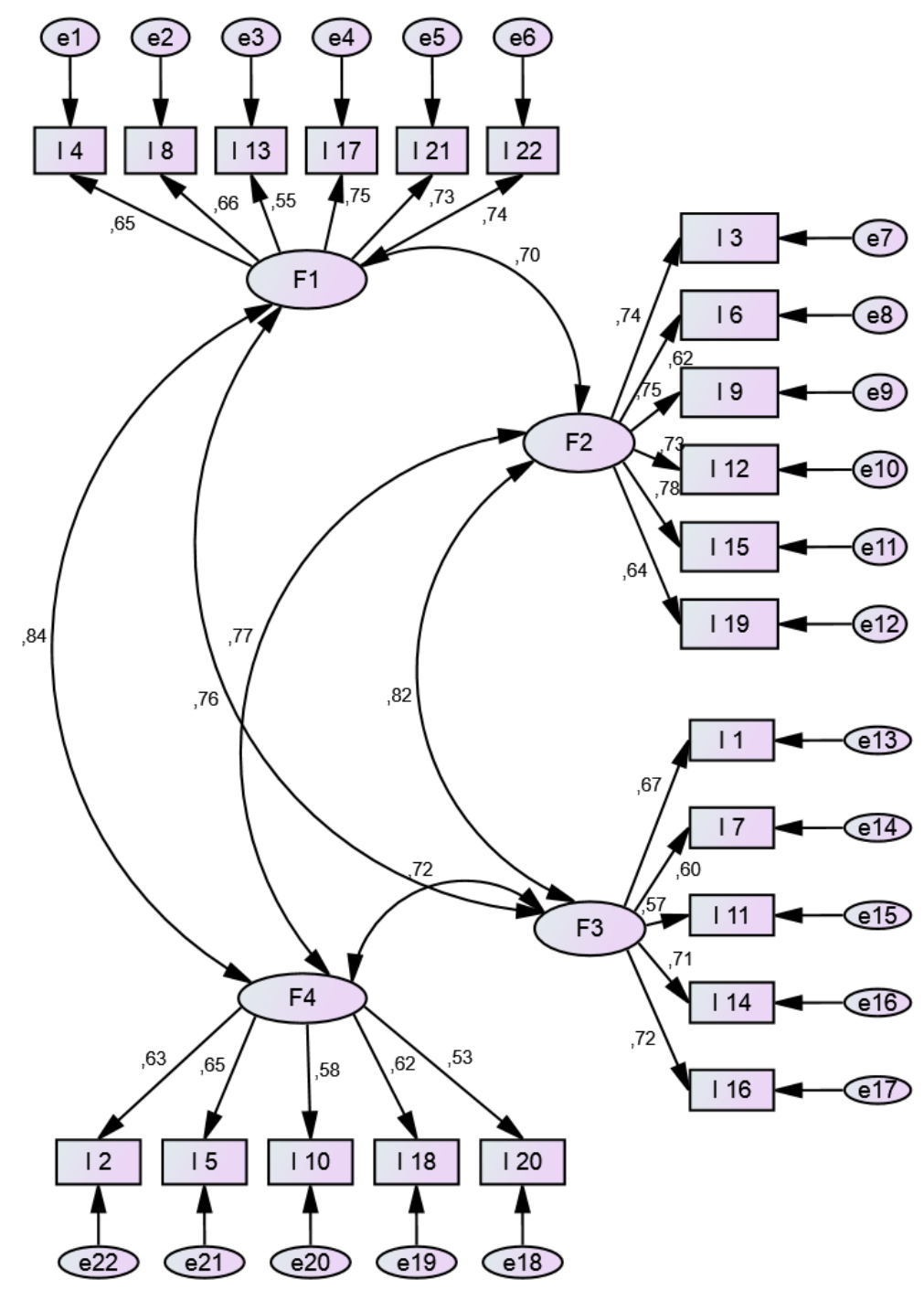

Figure 2. Confirmatory Factor Analysis results of the Scale

As a result of the Confirmatory Factor Analysis, it was confirmed that the 'Physics Course Attitudes Scale' consisted of 22 items and four factors.

\subsection{Findings on reliability}

Reliability is a concept that is related to whether or not a measurement instrument provides the same results in times of repeated application (Balc1, 2009; Baykul, 2000). As a result of the EFA, it was determined that the 'Physics Course Attitudes Scale' consisted of a total of 22 items and four factors. To determine the reliability rates of these factors in relation to internal consistency, their Cronbach's Alpha reliability coefficients were obtained. The Cronbach's 
Alpha reliability coefficients of the factors were as 0.911 for Interest, 0.906 for Unwillingness, 0.845 for Academic self and 0.782 for Necessity. The Cronbach's Alpha value for the entire scale was 0.936 . The Cronbach's Alpha coefficient takes values in the range of 0.00 to 1.00 . As the coefficient gets closer to 1.00, the reliability of the measurement instrument increases, while as it gets closer to 0.00 , the reliability decreases. In the social sciences, in general, Cronbach's Alpha coefficients of 0.60 or higher are seen to be sufficient. On the other hand, the reliability coefficient used for preparing and applying psychometric tests is expected to be 0.70 or higher (Büyüköztürk, 2002). According to the findings obtained, the internal consistency coefficients for the factors and the entire scale were quite high.

\section{DISCUSSION and CONCLUSION}

One thousand one hundred and eighteen high school students participated in this study, which was conducted to develop an up-to-date, valid and reliable 'Physics Course Attitudes Scale'. At the first stage of the study, to reveal the opinions of high school students on the physics course, a draft form with 58 items was obtained based on the data collected from the 152 high school students in the first sample. From this draft form, based on the opinions of seven experts including experts on 'measurement and assessment', 'curriculum development', 'physics' and 'linguistics', a 43-item scale form was prepared. The 43-item, 5-point Likert-type 'Physics Course Attitudes Scale' was applied to a total of 602 high school students studying at the city center of the province of Denizli in Turkey who constituted the second sample of the study. At this stage, 21 items that were found to be statistically unsuitable were removed. An EFA was conducted on the data of the remaining 22 items, and item-factor and item-test correlations were calculated. According to the results, the scale consists of four factors which are named as interest, unwillingness, academic self and necessity. For the remaining 22 items in the scale, all findings on the item factor loads, factor eigenvalues and ratios of explaining the total variance were examined. Furthermore, it was found that there was a significant relationship among these four factors, and there was no problem of autocorrelation. The final scale was applied on the third sample consisting of 364 high school students, and a CFA was carried out on the obtained data. The EFA results were also confirmed with the results of the CFA.

The reliability degrees of the entire scale and the four factors in relation to their internal consistency were obtained by calculating Cronbach's Alpha coefficients. The Cronbach's Alpha value for the entire scale was obtained as 0.936 . According to the findings, the internal consistency coefficients of the entire scale and the factors of the scale were high. The 'Physics Course Attitudes Scale' that was developed in this study, gathered under four factors and included 22 items containing 12 positive and 10 negative statements was found to be a valid and reliable scale based on the statistical data.

This scale which was developed with the purpose of revealing the attitudes of high school students towards the physics course is not only an up-to-date scale, but also a valid and reliable measurement instrument. For these reasons, this scale is believed to be an effective measurement instrument to determine and also monitor high school students' attitudes towards the physics course. The increases in the scores obtained from the scale is interpreted as a positive change towards the physics course. 


\section{Declaration of Conflicting Interests and Ethics}

The authors declare no conflict of interest. This research study complies with research publishing ethics. The scientific and legal responsibility for manuscripts published in IJATE belongs to the author(s).

\section{ORCID}

Hülya Çermik (D) https://orcid.org/0000-0002-5343-5441

İzzet Kara (iD) https://orcid.org/0000-0002-9837-2819

\section{REFERENCES}

Akpınar, M. (2006). Öğrencilerin fizik dersine yönelik tutumlarının fizik dersi akademik başarısına etkisi (Unpublished master's thesis). Gazi University, Institute of Educational Sciences, Ankara.

Angell, C., Guttersrud, Ø., Henriksen, E. K., \& Isnes, A. (2004). Physics: Frightful, but fun, Pupils' and teachers' views of physics and physics teaching. Science Education, 88, 683706.

Balc1, A. (2009). Sosyal bilimlerde araştırma: Yöntem, teknik ve ilkeler. Ankara: PegemA Yayınc1lik.

Baykul, Y. (2000). Ĕgitimde ve psikolojide ölçme: Klasik Test Teorisi ve uygulaması. Ankara: ÖSYM Yayınları.

Bayram, N. (2013). Yapısal eşitlik modellemesine giriş (2. bask1). Bursa: Ezgi Kitabevi.

Büyüköztürk, Ş. (2002). Sosyal bilimler için veri analizi el kitabı. Ankara: PegemA Yayıncılık.

Comrey, A. L., \& Lee, H. B. (1992). A first course in factor analysis (2 ${ }^{\text {nd }}$ ed.). Hillsdale, NJ: Lawrence Erlbaum Associates.

Douglas, K. A., Yale, M. S., Bennett, D. E., Haugan, M. P., \& Bryan, L. A. (2014). Evaluation of Colorado Learning Attitudes about Science Survey. Physical Review Special Topics Physics Education Research, 10(2), 1-10/020128.

Faour, M.A., \& Ayoubi, Z. (2018). The effect of using virtual laboratory on grade 10 students' conceptual understanding and their attitudes towards physics. Journal of Education in Science, Environment and Health, 4(1), 54-68.

Golob, T.F. (2003). Structural equation modeling for travel behavior research. Transportation Research, 37(1), 1-25.

Henson, R.K., \& Roberts, J.K. (2006). Use of exploratory factor analysis in published research: Common errors and some comment on improved practise. Educational and Psychological Measurement, 66(3), 393-416.

İnceoğlu, M. (2010). Tutum, algl, iletişim. İstanbul: Beykent Üniversitesi Yayınları, No: 69.

Kaur, D., \& Zhao, Y. (2017). Development of Physics Attitude Scale (PAS): An instrument to measure students' attitudes toward physics. Asia-Pacific Educational Researcher, 26(5), 291-304.

Kline, P. (1994). An easy guide to factor analysis. New York: Routledge

Korkmaz, Ö., Şahin, A., \& Yeşil, R. (2011). Bilimsel araştırmaya yönelik tutum ölçeği geçerlilik ve güvenirlik çalışması. Illköğretim Online, 10(3), 961-973.

Kurnaz, M.A., \& Yiğit, N. (2010). Fizik tutum ölçeği: Geliştirilmesi, geçerliliği ve güvenilirliğii. Necatibey Eğitim Fakültesi Elektronik Fen ve Matematik Ĕ̈itimi Dergisi, 4(1), 29-49.

Moll, R., \& Milner-Bolotin, M. (2009). The effect of interactive lecture experiments on student academic achievement and attitudes towards physics. Canadian Journal of Physics, 87(8), 917-924.

Mualem, R., \& Eylon, B.S. (2007). 'Physics with a smile'-Explaining phenomenon with a qualitative problem-solving strategy. Physics Teacher, 45(3), 158-163. 
Mulhall, P. J., \& Gunstone, R. (2008). Views about physics held by physics teachers with differing approaches to teaching physics. Research in Science Education, 38(4), 435-462.

Nalçacı, İ.Ö., Akarsu, B., \& Kariper, İ. A. (2011). Orta öğretim öğrencileri için fizik tutum ölçeği derlenmesi ve öğrenci tutumlarının değerlendirilmesi. Journal of European Education, 1(1), 1-6.

Olusola, O. O., \& Rotimi, C.O. (2012). Attitudes of students towards the study of physics in College of Education Ikere Ekiti, Ekiti State, Nigeria. American International Journal of Contemporary Research, 2(12), 86-89.

Özçelik, D.A. (1998). Ölçme ve değerlendirme. Ankara: ÖSYM Yayınları.

Özyürek, A., \& Eryılmaz, A. (2001). Ögrencilerin fizik dersine yönelik tutumlarını etkileyen etmenler. Eğitim ve Bilim Dergisi, 26(120), 21-28.

Papanastasiou, E.C., \& Zembylas, M. (2002). The effect of attitudes on science achievement: a study conducted among high school pupils in Cyprus. International Review of Education, $48(6), 469-484$.

Pohlmann, J. T. (2004). Use and interpretation of factor analysis in the journal of educational research: 1992-2002. The Journal of Educational Research, 98(1), 14-23.

Rivard, L.P., \& Straw, S.P. (2000). The effect of talk and writing on learning science: An exploratory study. Science Education, 84, 566-593.

Schumacker, R.E., \& Lomax, R.G. (2004). A Beginner's guide to Structural Equation Modeling $\left(2^{\text {nd }}\right.$ ed. $)$. NJ: Lawrence Erlbaum Associates, Mahwah.

Seçer, İ., (2015). Psikolojik test geliştirme ve uyarlama süreci. Ankara: Anı Yayıncıl1k.

Taşlidere, E. (2002). The effect of conceptual on students' achievement and attitudes toward physics (Unpublished master's thesis). Middle East Technical University, Institute of Science and Technology, Ankara.

Taşlidere, E., \& Eryılmaz, A. (2009). Alternative to traditional physics instruction: effectiveness of conceptual physics approach. Eurasion Journal of Educational Research, $35,109-128$.

Tekbıyık, A. (2010). Bağlam temelli yaklaşımla ortaöğretim 9. sınıf enerji ünitesine yönelik $5 E$ modeline uygun ders materyallerinin geliştirilmesi (Unpublished doctoral dissertation) Karadeniz Technical University, Institute of Science, Trabzon.

Tekbıyık, A., \& Akdeniz, A.R. (2010). Ortaöğretim öğrencilerine yönelik güncel fizik tutum ölçeği: Geliştirilmesi, geçerlik ve güvenirliği. Türk Fen Eğitimi Dergisi, 7(4), 134-144.

Uz, H., \& Eryılmaz, A., (1999). Effects of socioeconomic status, locus of control, prior achievement, cumulative gpa, future occupation and achievement in mathematics on students' attitudes toward physics. Hacettepe University Journal of Education, 17(17), 105-112.

Veloo, A., Nor, R., \& Khalid, R. (2015). Attitude towards physics and additional mathematics achievement towards physics achievement. International Education Studies, 8(3), 35-43.

Wang, Y., Lin, H., \& Luarn, P. (2006). Predicting consumer intention to use mobile service. Information Systems Journal, 16(2), 157-179.

Williams, C., Stanisstreet, M., Spall, K., \& Boyes, E. (2003). Why aren't secondary students interested in physics? Physics Education, 38(4), 324-329.

Yap, B.W., \& Khong, K.W. (2006). Examining the effects of customer service management (CSM) on perceived business performance via Structural Equation Modelling. Applied Stochastic Models in Business and Industry, 22, 587-605. 